\title{
The clinical characteristics of East Asian patients with Birt-Hogg-Dubé syndrome
}

\author{
Ting Guo ${ }^{1,2,3}$, Qinxue Shen ${ }^{1,2,3}$, Ruoyun Ouyang ${ }^{1,2,3}$, Min Song ${ }^{1,2,3}$, Dandan Zong ${ }^{1,2,3}$, Zhihui Shi ${ }^{1,2,3}$, \\ Yingjiao Long ${ }^{1,2,3}$, Ping Chen ${ }^{1,2,3}$, Hong Peng ${ }^{1,2,3}$ \\ ${ }^{1}$ Department of Respiratory and Critical Care Medicine, The Second Xiangya Hospital of Central-South University, Changsha, China; ${ }^{2}$ Research \\ Unit of Respiratory Disease, Central-South University, Changsha, China; ${ }^{3}$ The Respiratory Disease Diagnosis and Treatment Center of Hunan \\ Province, Changsha, China \\ Contributions: (I) Conception and design: H Peng, T Guo; (II) Administrative support: P Chen, H Peng; (III) Provision of study materials or patients: \\ Q Shen, R Ouyang, M Song, D Zong, Z Shi, Y Long; (IV) Collection and assembly of data: T Guo, Q Shen; (V) Data analysis and interpretation: All \\ authors; (VI) Manuscript writing: All authors; (VII) Final approval of manuscript: All authors. \\ Correspondence to: Hong Peng, MD, PhD. Department of Respiratory and Critical Care Medicine, The Second Xiangya Hospital of Central-South \\ University, NO. 139 Renmin Middle Road, Changsha 410011, China. Email: penghong66@csu.edu.cn.
}

Background: Birt-Hogg-Dube (BHD) syndrome is an autosomal dominant disease that has been characterized by skin lesions, multiple pulmonary cysts, spontaneous pneumothorax, and renal tumors, but the patients in Asian countries may show fewer symptoms. We aimed to explore and summarize the clinical features of BHD patients in East Asia to facilitate early diagnosis and timely interventions.

Methods: We collected and analyzed the clinical data of patients diagnosed with BHD in our hospital by reviewing medical records. We performed a systematic literature search regarding the presenting clinical features in BHD patients from China, Japan, and Korea and then reviewed the publications that were identified.

Results: In our hospital, 10 patients were diagnosed with BHD from April 2015 to September 2019. After reviewing the literature, we recruited 38 articles, including 12, 20, and 6 reports from China, Japan, and Korea, respectively. A total of 166 patients were included in this study, and 100 of them $(60.2 \%)$ were females. Multiple pulmonary cysts were present in 145 patients (87.3\%), and 124 patients $(74.7 \%)$ had a history of pneumothorax on at least one occasion. Skin biopsy confirmed fibrofolliculomas (FFs) alone in 22 patients (13.3\%), trichodiscomas (TDs) alone in 3 patients (1.8\%), and both FFs and TDs in 7 patients $(4.2 \%)$. Renal carcinoma only occurred in $12(7.2 \%)$ patients. The most frequent genetic mutations in East Asian patients were c.1285delC on exon 11 (18.4\%), c.1285dupC on exon 11 (18.4\%), and c.1347_1353dupCCACCCT on exon 12 (8.2\%).

Conclusions: Our findings suggested that pulmonary cysts are the most frequent radiological findings, and pneumothorax is the most common symptom in East Asian patients with BHD, and that skin lesions and kidney involvement are less frequent. To make an early diagnosis and minimize the severity of complications, careful observation, and timely genetic examination of the FLCN gene is essential.

Keywords: Birt-Hogg-Dube syndrome (BHD syndrome); East Asia; pulmonary cysts; pneumothorax

Submitted Jan 31, 2020. Accepted for publication Aug 28, 2020.

doi: $10.21037 / \mathrm{atm}-20-1129$

View this article at: http://dx.doi.org/10.21037/atm-20-1129 


\section{Introduction}

Birt-Hogg-Dube (BHD) syndrome is an autosomal dominant disorder characterized by skin fibrofolliculomas (FFs), renal cancer, and multiple lung cysts with spontaneous pneumothorax $(1,2)$. This syndrome is caused by germline mutations in the FLCN gene located on the short arm of chromosome 17 (17p11.2). Folliculin, the highly conserved tumor suppressor protein, is encoded by FLCN and is widely expressed in skin, kidney, and alveolar epithelial cells (3). Those affected may present with a single organ lesion or with multiple cutaneous lesions, multiple lung cysts, and bilateral renal tumors.

In previous studies, typical skin lesions and renal tumors have been more frequently observed in BHD patients diagnosed in Europe and the United States, where typical skin FFs were reported in $82-90 \%$ of BHD patients, and renal tumors ranged from $13.4-45 \%(2,4-6)$. In other areas, the clinical presentations have also shown some differences. A Japanese study (7) investigated 156 FLCN mutation carriers, and 76 of them had skin papules; however, only six $(3.8 \%)$ were confirmed as typical FFs. Lee et al. (8) conducted a retrospective study, including 12 Korean BHD patients, and only two of those patients' skin lesions were verified as FFs. In China, Liu et al. (9) identified 27 patients with FLCN mutations, and the minority of them showed skin lesions or renal tumors. These studies suggest that clinical characteristics may show discrepancies among different populations. However, the information about BHD patients in East Asian countries is limited, and a comprehensive study is needed.

In this study, we provided the clinical information of 10 BHD patients in our hospital, and we performed a systematic literature review to analyze and summarize the clinical features of BHD patients in the East Asian population. Due to a lack of awareness, there is commonly a delay in achieving a diagnosis of BHD syndrome, and patients are frequently misdiagnosed as having chronic obstructive lung disease (COPD), emphysema, common bullae/blebs, or other diseases $(4,10,11)$. The present study aimed to highlight the prevalent characteristics of BHD in the East Asian population in order to assist the correct diagnosis and treatment of BHD syndrome in its early stage.

We present the following article in accordance with the MDAR reporting checklist (available at http://dx.doi. org/10.21037/atm-20-1129).

\section{Methods}

\section{Study population}

A total of 10 patients who had been receiving medical care at the Second Xiangya Hospital of Central-South University and were diagnosed with BHD syndrome from April 2015 to September 2019 were enrolled in this study. The diagnosis of BHD syndrome was based on the criteria proposed by the European BHD consortium published in The Lancet Oncol, 2009 (10). The diagnosis was made when patients fulfilled at least one major or two minor criteria. The major criteria were as follows: (I) at least five fibrofolliculomas or trichodiscomas (at least one histologically confirmed, of adult-onset); (II) pathogenic FLCN germline mutation. The minor criteria were as follows: (I) multiple lung cysts (bilateral basally located lung cysts with no other apparent cause, with or without spontaneous primary pneumothorax); (II) renal cancer (early-onset before age 50, or multifocal or bilateral, or mixed chromophobe and oncocytic histology); (III) a firstdegree relative with BHD.

The trial was conducted in accordance with the Declaration of Helsinki. The study was approved by the institutional review board of the Second Xiangya Hospital of Central-South University (NO. 2014S009) and informed consent was taken from all the patients.

\section{Review of the literature}

Three PubMed searches with the term "Birt-Hogg-Dubé syndrome" and "China", "Korea", "Japan", respectively, were performed in September 2019. Articles were restricted to those published and available as full texts in the English language; conference abstracts were excluded. Articles were not included if they were case-control studies, review articles, including systematic analysis and meta-analysis, non-clinical studies, and original studies without sufficient clinical data.

\section{Statistical analysis}

The continuous variables were summarized as means and standard deviations. For categorical variables, the percentages of patients in each category were calculated. All analyses were done with SPSS software, 
Table 1 Baseline characteristics of the study population $(\mathrm{n}=10)$

\begin{tabular}{lc}
\hline Characteristics & Value \\
\hline Age, year & $54.4 \pm 7.5$ \\
Female & $8(80.0)$ \\
Smoking & $2(20.0)$ \\
Initial presentation & \\
Pneumothorax & $9(90.0)$ \\
Asymptomatic screening & $1(10.0)$ \\
Age of the first pneumothorax & $44.3 \pm 13.9$ \\
Pulmonary cysts & $10(100.0)$ \\
Kidney lesions & $2(20.0)$ \\
Skin lesions & $1(10.0)$ \\
Family history & $5(50.0)$ \\
\hline
\end{tabular}

Values are presented as mean \pm SD or number (\%). version 24.0

\section{Results}

\section{Study population}

Our study involved 10 independent individuals from different families, who were diagnosed with BHD in our hospital. Among them, only two patients were males. The mean diagnostic age was 54.4 years, and $20 \%$ were current smokers. All patients had CT-detectable pulmonary cysts. Pneumothorax was the most common initial manifestation in 9 of the participants. The mean age of first pneumothorax was 44.3 years. Only 2 of the patients had renal lesions at the time of diagnosis, 1 had renal cysts, and the other 1 had renal clearcell carcinoma. Skin involvement was present in 1 patient. The clinical characteristics are summarized in Tables 1,2.

Table 2 Clinical features of the study population $(n=10)$

\begin{tabular}{|c|c|c|c|c|c|c|c|c|c|}
\hline $\begin{array}{l}\text { Patient } \\
\text { No. }\end{array}$ & Age/Sex & $\begin{array}{l}\text { Smoking } \\
\text { history }\end{array}$ & $\begin{array}{l}\text { PTX } \\
\text { Age }^{\dagger}\end{array}$ & Kidney & Skin & $\begin{array}{c}\text { Site of FLCN } \\
\text { mutation }\end{array}$ & Nucleotide changes & $\begin{array}{l}\text { Other } \\
\text { presentations }\end{array}$ & $\begin{array}{l}\text { Family history } \\
\text { (NO.) }\end{array}$ \\
\hline 1 & $62 / \mathrm{M}$ & Current & 26 & $\begin{array}{l}\text { Simple cysts } \\
\text { (bilateral, } \\
\text { multiple, up } \\
\text { to } 1.7 \mathrm{~cm} \text { ) }\end{array}$ & - & Exon 11 & c. $1285 \mathrm{delC}$ & - & $\begin{array}{c}\text { Pulmonary cyst } \\
\text { (3; younger sister, } \\
\text { younger brother, son) }\end{array}$ \\
\hline 3 & $58 / \mathrm{M}$ & Current & - & - & - & Exon 11 & c.1285dupC & - & - \\
\hline 4 & $61 / F$ & Never & 61 & - & - & $\mathrm{N} / \mathrm{A}$ & $\mathrm{N} / \mathrm{A}$ & - & $\operatorname{BHD}(1 ;$ son $)$ \\
\hline 5 & $53 / F$ & Never & 25 & - & - & Exon 11 & c. 1285 dupC & - & - \\
\hline 7 & $64 / F$ & Never & 62 & - & $+($ not biopsied $)$ & Exon 13 & c.1533_1536delGATG & Liver cyst & - \\
\hline 8 & $51 / F$ & Never & 38 & - & - & Exon 6 & c.924_926del & Thyroid nodule & $\begin{array}{c}\text { BHD (3; mother, } \\
\text { younger sister, son) }\end{array}$ \\
\hline 9 & $42 / F$ & Never & 42 & - & - & Exon 14 & c.1579_1580insA & - & - \\
\hline 10 & $59 / F$ & Never & 58 & - & - & Exon 11 & c. $1285 \mathrm{delC}$ & - & - \\
\hline
\end{tabular}

\footnotetext{
${ }^{\dagger}$ Age of the first pneumothorax; PTX, pneumothorax; FLCN, folliculin gene; BHD, Birt-Hogg-Dubé syndrome; RCC, renal cell carcinoma;
} $\mathrm{Rt}$, right-sided; Lt, left-sided. 


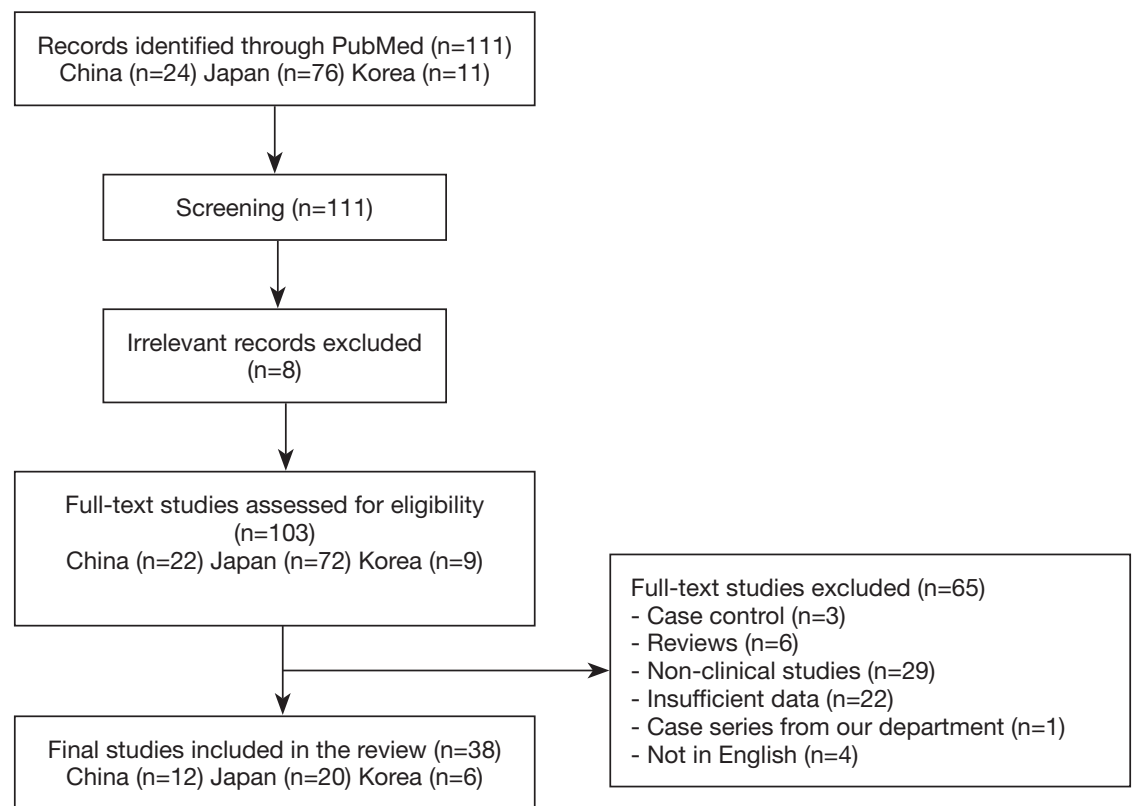

Figure 1 Flow chart summarizing studies that are included in the systematic review based on the predefined inclusion and exclusion criteria.

\section{Review of the literature}

There were 111 articles relating to reports of Birt-HoggDubé syndrome in China, Korea, or Japan retrieved from the PubMed database. We excluded 73 studies due to their failure to meet our eligibility criteria. A flow chart summarizing the inclusion and exclusion criteria of the searched studies is presented in Figure 1. Ultimately, a total of 38 reports were included in this study; there were 12, 20, and 6 reports from China, Japan, and Korea, respectively. Detailed characteristics of all of the studies included are provided in Tables 3-5.

A total of 166 East Asian patients were enrolled in this study from 38 articles; this number included the 10 patients that we recruited. Among these 166 patients, 100 (60.2\%) were females. Multiple pulmonary cysts were presented in 145 patients $(87.3 \%)$, and 124 patients $(74.7 \%)$ had a history of at least one pneumothorax. Skin lesions were detected in 61 patients $(36.7 \%)$, of whom 23 did not undergo a pathological biopsy. Skin biopsy confirmed fibrofolliculomas (FFs) alone, trichodiscomas (TDs) alone, and FFs and TDs in 22 patients $(13.3 \%), 3$ patients $(1.8 \%)$, and 7 patients $(4.2 \%)$ respectively. Other skin lesions detected included sarcoma cutis $(1,0.6 \%)$, milia $(1,0.6 \%)$, mucinosis (1, $0.6 \%)$, angiofibroma $(1,0.6 \%)$, syringoma $(1,0.6 \%)$, and perifollicular fibromas (1, $0.6 \%)$. Renal involvement had developed in 38 patients $(22.9 \%)$ at the time of diagnosis, and the renal lesions included renal cysts $(22,13.3 \%)$, renal cell carcinoma (RCC) (12, 7.2\%), hamartoma (2, 1.2\%), oncocytoma $(1,0.6 \%)$, and angiomyolipoma $(1,0.6 \%)$. The information above is provided in Table 6.

The mutations of BHD in enrolled patients are listed in Table 7. The details of genetic mutations were not clear in 19 patients. Among 147 BHD patients with definite information about mutation site, c. $1285 \mathrm{delC}$ on exon 11 (18.4\%), c.1285dupC on exon 11 (18.4\%), and c.1347_1353dupCCACCCT on exon 12 (8.2\%) were the most frequent BHD mutations. The identified mutation sites included introns 4, 5, 7, 9, 10, 11, and exons 4, 5, 6, 7, $8,9,10,11,12,13$, and 14 . Exon 11 was the most common site of mutation $(37.4 \%)$, followed by exon 14 (10.2\%), exon $12(10.2 \%)$, and exon 6 (9.5\%).

\section{Discussion}

BHD syndrome was initially described in 1977 (1) as an association of 3 characteristic cutaneous lesions: FFs, TDs, and acrochordon. The first description of pneumothorax in association with these lesions was reported in 1986 (48). In 1993, a case of renal cancer associated with FFs was reported (49). More recent studies have shown that the $F L C N$ gene plays a role in inhibiting RCC and skin FFs that are associated with BHD. However, the role of FLCN in the development of pulmonary cysts (PCs) remains unclear. 
Table 3 Clinical findings of the BHD cases diagnosed in Chinese population

\begin{tabular}{|c|c|c|c|c|c|c|c|c|c|}
\hline $\begin{array}{l}\text { First author, year } \\
\text { (no. patients) }\end{array}$ & Country & Males & Females & $\begin{array}{l}\text { Family } \\
\text { history }\end{array}$ & $\begin{array}{l}\text { Pulmonary } \\
\text { cysts }\end{array}$ & PTX & Skin histology & Renal lesions & $\begin{array}{c}\text { FLCN } \\
\text { mutation }\end{array}$ \\
\hline $\begin{array}{l}\text { Huajie Xing et al. (12) } \\
2017(n=18)\end{array}$ & China & 10 & 8 & PTX & $8 / 18$ & $6 / 18$ & - & - & $17 / 18$ \\
\hline $\begin{array}{l}\text { Yaping Liu et al. (9) } \\
2017(n=27)\end{array}$ & China & 3 & 24 & $\begin{array}{l}\text { Pulmonary } \\
\text { bulla; PTX }\end{array}$ & $25 / 27$ & $20 / 27$ & $\begin{array}{l}3 / 27 \text { (2 FFs; } 1 \\
\text { sarcoma cutis) }\end{array}$ & $\begin{array}{l}6 / 27 \text { (4 renal cysts; } \\
2 \text { hamartoma) }\end{array}$ & $27 / 27$ \\
\hline $\begin{array}{l}\text { Teng Li et al. (14) } \\
2017(n=2)\end{array}$ & China & 2 & - & PTX & $\mathrm{N} / \mathrm{A}$ & $2 / 2$ & - & 2/2 (2 RCC) & $2 / 2$ \\
\hline $\begin{array}{l}\text { Li Dong et al. (15) } \\
2016(n=2)\end{array}$ & China & 2 & - & $\mathrm{N} / \mathrm{A}$ & - & - & 2/2 (not biopsied) & 2/2 (2 RCC) & $2 / 2$ \\
\hline $\begin{array}{l}\text { Xiaocan Hou et al. } \\
\text { (17) } 2018(n=8)\end{array}$ & China & 4 & 4 & PTX & $6 / 8$ & $7 / 8$ & 1/8 (not biopsied) & 1/8 (1 renal cysts) & $8 / 8$ \\
\hline $\begin{array}{l}\text { JF Zhu et al. (18) } \\
2017(n=1)\end{array}$ & China & - & 1 & PTX & + & + & - & - & + \\
\hline $\begin{array}{l}\text { Gee Gwo Yang } \\
\text { et al. (19) } 2013(n=1)\end{array}$ & China & - & 1 & PTX & + & + & - & - & + \\
\hline $\begin{array}{l}\text { Zhibo Liu et al. (20) } \\
2014(n=4)\end{array}$ & China & 2 & 2 & PTX & $4 / 4$ & $1 / 4$ & - & - & $4 / 4$ \\
\hline $\begin{array}{l}\text { Zhichun Lin et al. } \\
\text { (21) } 2014(n=2)\end{array}$ & China & 1 & 1 & N/A & $2 / 2$ & $1 / 2$ & 1/2 (not biopsied) & $1 / 2(\mathrm{RCC})$ & $2 / 2$ \\
\hline
\end{tabular}

N/A, data not available; PTX, pneumothorax; FLCN, folliculin gene; BHD, Birt-Hogg-Dubé syndrome; RCC, renal cell carcinoma; FFs, fibrofolliculomas; TDs, trichodiscomas; PFs, perifollicular fibromas.

Researchers have concluded that PCs associated with BHD are a distinct entity and can be considered to be hamartomalike lesions associated with the dysfunctional mammalian target of rapamycin (mTOR) signaling $(50,51)$. The protein kinase mTOR regulates cell growth, proliferation, movement, and protein synthesis and transport.

Multiple PCs with repeated pneumothorax, renal tumors, and FFs are currently the three main manifestations of BHD. Toro et al. (4) reported that FFs are present in $90 \%$ of the families with BHD in Europe and the United States. Renal tumors and FFs are also present in more than $27 \%$ and $80 \%$ of these BHD patients, respectively $(10,52)$. In Europe and the United States, BHD is well known, and treatment approaches are established. In contrast,
BHD is not yet well known in Asia, and this may be due to differences in the major presenting symptoms of BHD. In China, BHD syndrome is not commonly reported, and few patients show all the typical signs, including PCs, renal tumors, and skin lesions. Liu et al. (9) studied 27 Chinese patients with FLCN mutation, and among them, 25 patients (92.6\%) had multiple PCs, while only two patients had FFs (7.4\%), and no patients had developed renal tumors at the time of diagnosis. In our case series, all 10 BHD patients (100.0\%) had multiple PCs, and only one patient showed skin lesions. Kidney lesions were also relatively rare, RCC was detected in 1 patient, and 1 patient had renal cysts. In combination with the other 12 reports relating to Chinese patients, we deduced that PCs and pneumothorax were the 
Table 4 Clinical findings of the BHD cases diagnosed in Korean population

\begin{tabular}{|c|c|c|c|c|c|c|c|c|c|}
\hline $\begin{array}{l}\text { First author, year } \\
\text { (no. patients) }\end{array}$ & Country & Males & Females & $\begin{array}{l}\text { Family } \\
\text { history }\end{array}$ & $\begin{array}{l}\text { Pulmonary } \\
\text { cysts }\end{array}$ & PTX & Skin histology & Renal lesions & $\begin{array}{c}\text { FLCN } \\
\text { mutation }\end{array}$ \\
\hline $\begin{array}{l}\text { Joo Hee Lee et al. (8) } \\
2018(n=12)\end{array}$ & Korea & 4 & 8 & $\begin{array}{c}\text { PTX; Skin } \\
\text { lesion; RCC }\end{array}$ & $12 / 12$ & $8 / 12$ & $\begin{array}{c}\text { 6/12 (2 FFs; } 1 \text { milia; } 1 \\
\text { mucinosis; } 1 \text { angiofibroma; } 1 \\
\text { not biopsied) }\end{array}$ & $\begin{array}{l}\text { 5/12 (2 renal } \\
\text { cysts; } 2 \text { RCC; } 1 \\
\text { oncocytoma) }\end{array}$ & $10 / 12$ \\
\hline $\begin{array}{l}\text { Kyung Soo Kim et al. } \\
\text { (23) } 2017(n=1)\end{array}$ & Korea & - & 1 & PTX & + & + & - & - & + \\
\hline $\begin{array}{l}\text { Won Woong Shin } \\
\text { et al. (25) } 2011(n=1)\end{array}$ & Korea & 1 & - & - & + & + & $+(\mathrm{FFs})$ & Renal cysts & + \\
\hline $\begin{array}{l}\text { Geon Park et al. (26) } \\
2011(n=1)\end{array}$ & Korea & 1 & - & $\begin{array}{l}\text { PTX; Skin } \\
\text { lesions }\end{array}$ & - & - & $+($ FFs and TDs) & - & + \\
\hline Total $(n=17)$ & & 6 & 11 & & 16 & 12 & 10 & 6 & 15 \\
\hline
\end{tabular}

N/A, Data not available; PTX, pneumothorax; FLCN, folliculin gene; BHD, Birt-Hogg-Dubé syndrome; RCC, renal cell carcinoma; FFs, fibrofolliculomas; TDs, trichodiscomas; PFs, perifollicular fibromas.

main manifestations of BHD patients in China, with skin and kidney lesions being not as common as in patients in Europe or the United States.

Limited articles were referring to BHD patients in Korea in our search, and most of them were case reports. A Korean retrospective study (8) involving 12 BHD patients showed only 2 patients with FFs and 2 patients with RCC. Skin lesions and kidney lesions seemed more frequent in Korean BHD patients, but typical FFs or TDs were found only in 5 patients, and RCCs were reported in 2 patients. In Japan, Furuya et al. (7) found that 139 individuals had radiologically determinable cysts out of 142 FLCN mutation carriers, 31 of 120 BHD probands indicated RCC, and 76 of 156 FLCN mutation carriers had skin lesions detected by physicians; however, most of them did not receive a histological examination. Their research suggested PCs are also main manifestations in Japanese BHD patients, and that RCC and skin lesions are less common. The results of our literature review confirmed those of previous studies. We excluded the study from Furuya et al. in our literature review due to difficulties in statistical analysis. All the above considered, compared to BHD patients in Europe or the United States, PCs and pneumothorax are the most frequent manifestations in East Asian patients, while skin lesions and kidney involvements are less common. A probable explanation for this discrepancy may be the ethnic backgrounds of the patients. No obvious differences in major genetic mutations between East Asian patients and patients from other areas were found, as the most frequent mutations in our study were c. $1285 \mathrm{delC}$ on exon 11 , c.1285dupC on exon 11, and c.1347_1353dupCCACCCT on exon 12, which were similar to those in Europe and the USA $(4,10)$. Whether the clinical difference was determined by other, less frequent genetic mutations is still unknown; a comparative study is needed in the future to explore the underlying gene discrepancy.

This report confirms that cutaneous manifestations are less identifiable in East Asian BHD patients, but FFs and TDs are still the predominant lesions in those patients with skin manifestations. Angiofibroma and perifollicular fibromas might also be considered as BHD-associated skin lesions (53). Other skin lesions, including sarcoma cutis, milia, mucinosis, and syringoma, have been seldom reported, and whether they are part of the clinical spectrum of BHD remains to be investigated. Skin neoplasms including malignant melanoma, cutaneous leiomyoma, dermatofibrosarcoma protuberans, basal cell carcinoma, and squamous cell carcinoma have been reported in Caucasian BHD patients $(11,54)$, but there is no similar patient report in the East Asian population. Renal cancer is the most threatening complication of BHD in Caucasians; Pavlovich et al. (55) indicated that $27 \%$ of BHD individuals 
Table 5 Clinical findings of the BHD cases diagnosed in Japanese population

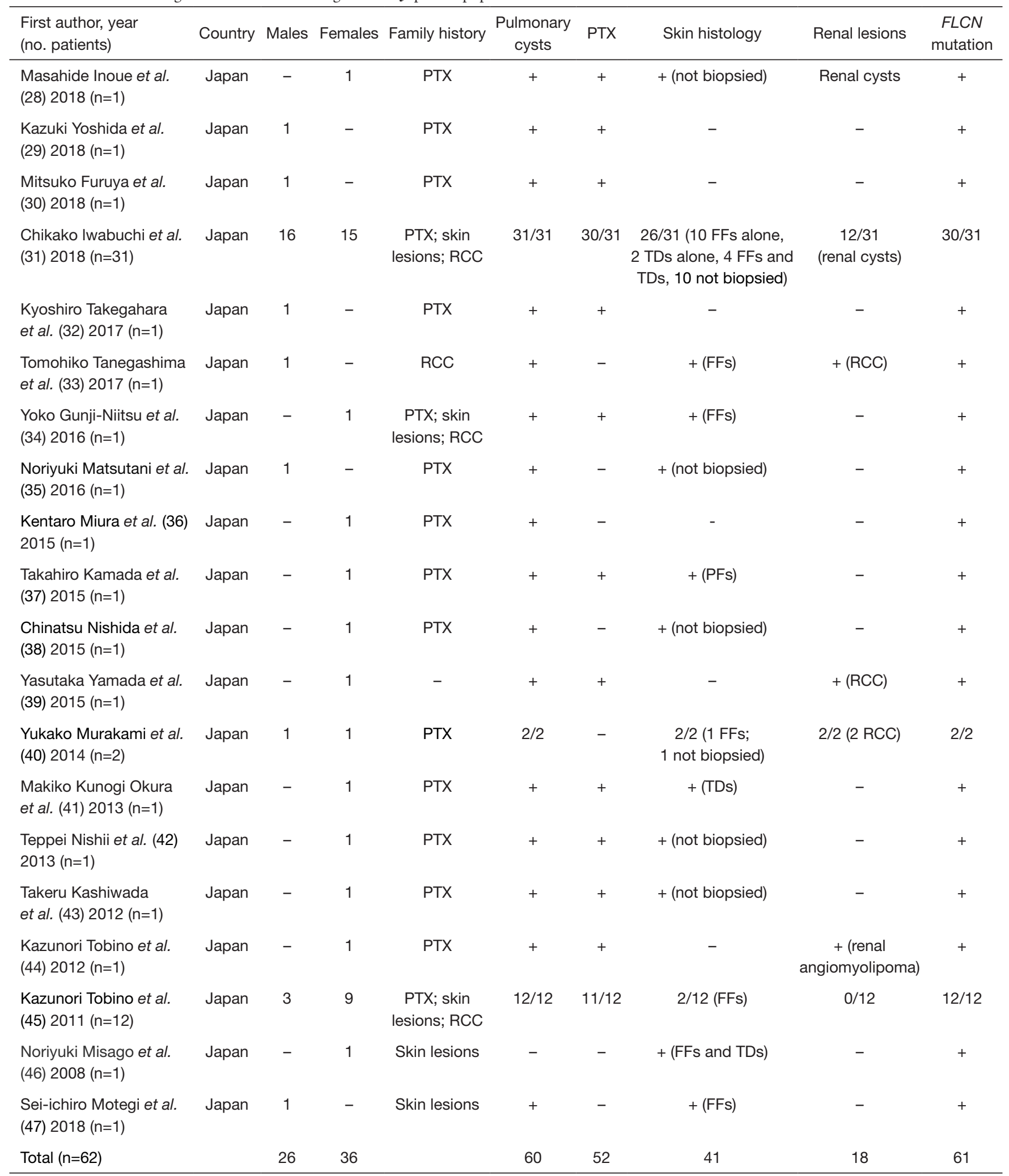

N/A, Data not available; PTX, pneumothorax; FLCN, folliculin gene; BHD, Birt-Hogg-Dubé syndrome; RCC, renal cell carcinoma; FFs, fibrofolliculomas; TDs, trichodiscomas; PFs, perifollicular fibromas. 
Table 6 Comparation of clinical features among three counties

\begin{tabular}{lcccccccc}
\hline Country & Patients & Males & Females & Pulmonary cysts & Pneumothorax & Skin lesions & Kidney lesions & FLCN mutation \\
\hline China & 87 & $34(39.1)$ & $53(60.9)$ & $69(79.3)$ & $60(69.0)$ & $10(11.5)$ & $14(16.1)$ & $85(97.7)$ \\
Korea & 17 & $6(35.3)$ & $11(64.7)$ & $16(94.1)$ & $12(70.6)$ & $10(58.8)$ & $6(35.3)$ & $15(88.2)$ \\
Japan & 62 & $26(41.9)$ & $36(58.1)$ & $60(96.8)$ & $52(83.9)$ & $41(66.1)$ & $18(29.0)$ & $61(98.4)$ \\
Total & 166 & $66(39.8)$ & $100(60.2)$ & $145(87.3)$ & $124(74.7)$ & $61(36.7)$ & $38(22.9)$ & $161(97.0)$ \\
\hline
\end{tabular}

Data are presented as number (\%).

Table 7 FLCN gene mutations of patients among three countries

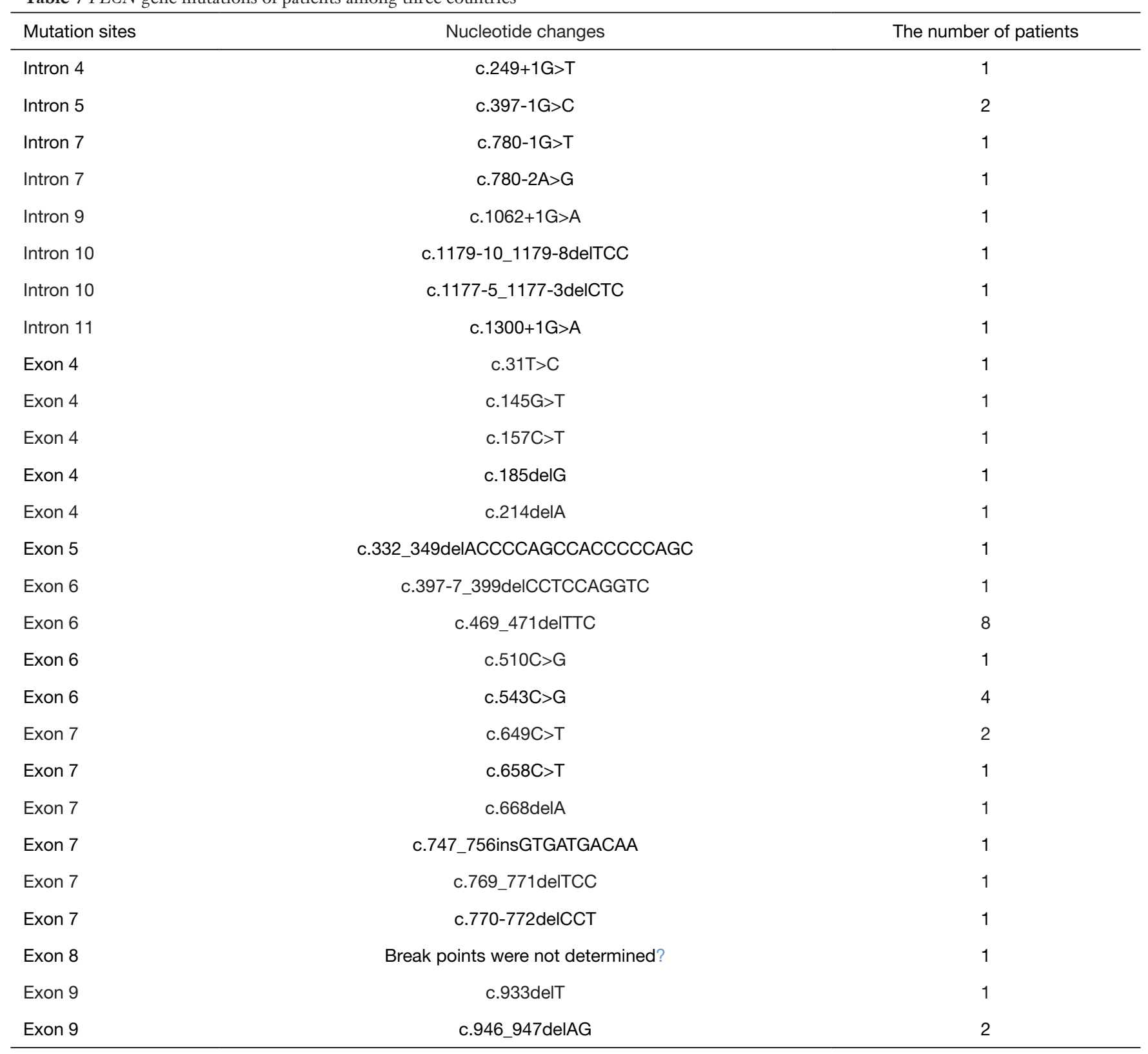

Table 7 (continued) 
Table 7 (continued)

\begin{tabular}{|c|c|c|}
\hline Mutation sites & Nucleotide changes & The number of patients \\
\hline Exon 10 & c. $1067 \mathrm{~T}>\mathrm{C}$ & 1 \\
\hline Exon 10 & c. $1135 \mathrm{~A}>\mathrm{T}$ & 1 \\
\hline Exon 10 & c. $1153 C>T$ & 2 \\
\hline Exon 10 & c. $1165 \mathrm{G}>\mathrm{T}$ & 1 \\
\hline Exon 10 & Genomic deletion of exon 10 & 1 \\
\hline Exon 11 & c. $1285 \mathrm{C}>\mathrm{T}$ & 1 \\
\hline Exon 11 & c.1285dupC & 27 \\
\hline Exon 12 & c.1379_1380delTC & 1 \\
\hline Exon 12 & c. $1429 \mathrm{C}>\mathrm{T}$ & 2 \\
\hline Exon 13 & c. $1481 A>G$ & 1 \\
\hline Exon 13 & c.1522_1524delAAG & 2 \\
\hline Exon 13 & c.1533_1536delGATG & 6 \\
\hline Exon 13 & c. $1533 \mathrm{G}>\mathrm{A}$ & 1 \\
\hline Exon 14 & c.1557delT & 3 \\
\hline Exon 14 & c.1579_1580insA & 7 \\
\hline Unclear & Unclear & 19 \\
\hline Negative & - & 1 \\
\hline Total & & 166 \\
\hline
\end{tabular}

had renal tumors, and Zbar et al. (56) found a 7-fold increase in the risk of renal tumors for BHD-affected patients. According to our review, though 38 (22.9\%) BHD individuals had kidney lesions, only 12 (7.2\%) had RCC in this East Asian patient group. Some of the patients had benign renal cysts, but the exact frequency of these cysts in comparison with the prevalence in the general population is currently unknown. Renal hamartoma, oncocytoma, and angiomyolipoma were reported in China, Korea, and
Japan, respectively. Byrne et al. (57) had never reported an Australian BHD patient with renal angiomyolipoma before their research. This phenomenon suggests that FLCN and tuberous sclerosis complex (TSC) proteins may function on a common pathway involving mTOR, as angiomyolipoma occurs in $69 \%$ of patients with TSC. Renal oncocytoma is regarded as a $\mathrm{BHD}$-associated renal manifestation and comprises a $3 \%$ proportion of $\mathrm{BHD}$ renal lesions in an American study (52). 
Although the majority of patients in our study were female, BHD syndrome is usually regarded as an autosomal dominant disease without gender discrimination, and some studies have supported this aspect. For example, a large Canadian family involving 36 members with FLCN mutations did not show a discrepancy in genders (58), and the study from Zbar et al. (56) also showed similar rates in males and females. Meanwhile, some other articles show a higher frequency of these mutations in females. Toro et al. (4) studied the clinical information of 89 individuals with FLCN mutations, and among them, 52 (58\%) were women. In their studies from East Asia, Lee et al. (8) and Liu et al. (9) showed that there was a higher frequency in females. This phenomenon may be associated with the bias of symptoms. In East Asian patients, according to our literature review, skin lesions and renal tumors are not common, and PCs, as well as pneumothorax, are the main manifestations, which may be misdiagnosed as other diseases. In China, particularly, COPD mainly occurs in males with a history of smoking (59). So we speculate that some males with BHD have not been properly diagnosed, and have been misdiagnosed with COPD. More epidemiological data are needed to confirm whether there is a gender dominance for BHD syndrome in East Asia.

There were several limitations to our study. Although it revealed that fewer typical skin lesions and renal tumors were present in East Asian patients with BHD and that pulmonary cysts with pneumothorax were the most common manifestations, we could not find the fundamental causes of these different clinical characteristics. The main genetic mutations of East Asian patients were similar to those in other areas, and it is still unknown whether other, less frequent genetic mutations determined the clinical differences. Medical habits or diagnostic processes may be different in these regions. Patients presenting with only skin lesions may potentially be overlooked, and those who had pulmonary cysts with pneumothorax may be misdiagnosed. All of these reasons can lead to clinical discrepancies between East Asia and Europe/USA. A large comparative study is necessary and needed in the future, concurrently in East Asia and Europe/USA, to explore these discrepancies.

\section{Conclusions}

Overall, the findings of the case series we presented, combined with the symptoms of other East Asian people diagnosed with BHD, have enhanced our understanding of BHD syndrome. It has also been highlighted that patients with multiple pulmonary cysts and spontaneous pneumothorax should be considered for BHD syndrome, independent of whether a skin rash or renal tumors are presented, particularly among individuals of the East Asian population.

\section{Acknowledgments}

Funding: This work was supported by the National Natural Science Foundation of China (grant number 81370164 and 81670062) and the Natural Science Foundation of Hunan Province (grant number 2015JJ4087 and 2020JJ8070) and the Fundamental Research Funds for the Central Universities of Central South University (No. 2020zzts880) and the China Scholarship Council (No. 201906370230).

\section{Footnote}

Reporting Checklist: The authors have completed the MDAR reporting checklist. Available at http://dx.doi.org/10.21037/ atm-20-1129

Data Sharing Statement: Available at http://dx.doi. org/10.21037/atm-20-1129

Peer Review File: Available at http://dx.doi.org/10.21037/ atm-20-1129

Conflicts of Interest: All authors have completed the ICMJE uniform disclosure form (Available at http://dx.doi. org/10.21037/atm-20-1129). The authors have no conflicts of interest to declare.

Ethical Statement: The authors are accountable for all aspects of the work in ensuring that questions related to the accuracy or integrity of any part of the work are appropriately investigated and resolved. The trial was conducted in accordance with the Declaration of Helsinki. The study was approved by the institutional review board of the Second Xiangya Hospital of Central-South University (NO. 2014S009) and informed consent was taken from all the patients.

Open Access Statement: This is an Open Access article distributed in accordance with the Creative Commons Attribution-NonCommercial-NoDerivs 4.0 International License (CC BY-NC-ND 4.0), which permits the noncommercial replication and distribution of the article with 
the strict proviso that no changes or edits are made and the original work is properly cited (including links to both the formal publication through the relevant DOI and the license). See: https://creativecommons.org/licenses/by-nc-nd/4.0/.

\section{References}

1. Birt AR, Hogg GR, and Dube WJ. Hereditary multiple fibrofolliculomas with trichodiscomas and acrochordons. Arch Dermatol 1977;113:1674-7.

2. Schmidt LS, Nickerson ML, Warren MB, et al. Germline BHD-mutation spectrum and phenotype analysis of a large cohort of families with Birt-Hogg-Dube syndrome. Am J Hum Genet 2005;76:1023-33.

3. Schmidt LS, Warren MB, Nickerson ML, et al. BirtHogg-Dube syndrome, a genodermatosis associated with spontaneous pneumothorax and kidney neoplasia, maps to chromosome 17p11.2. Am J Hum Genet 2001;69:876-82.

4. Toro JR, Wei MH, Glenn GM, et al. BHD mutations, clinical and molecular genetic investigations of BirtHogg-Dubé syndrome: a new series of 50 families and a review of published reports. J Med Genet 2008;45:321-31.

5. Johannesma PC, van de Beek I, van der Wel TJWT, et al. Renal imaging in 199 Dutch patients with Birt-HoggDubé syndrome: Screening compliance and outcome. PLoS One 2019;14:e0212952.

6. Kluger N, Giraud S, Coupier I, et al. Birt-Hogg-Dubé syndrome: clinical and genetic studies of 10 French families. Br J Dermatol 2010;162:527-37.

7. Furuya M, Yao M, Tanaka R, et al. Genetic, epidemiologic and clinicopathologic studies of Japanese Asian patients with Birt-Hogg-Dube syndrome. Clin Genet 2016;90:403-12.

8. Lee JH, Jeon MJ, Song JS, et al. Birt-Hogg-Dubé syndrome in Korean: clinicoradiologic features and long term follow-up. Korean J Intern Med 2019;34:830-40.

9. Liu Y, Xu Z, Feng R, et al. Clinical and genetic characteristics of chinese patients with Birt-Hogg-Dube syndrome. Orphanet J Rare Dis 2017;12:104.

10. Menko FH, Van Steensel MA, Giraud S, et al. Birt-HoggDube syndrome: diagnosis and management. Lancet Oncol 2009;10:1199-206.

11. Toro JR, Pautler SE, Stewart L, et al. Lung cysts, spontaneous pneumothorax, and genetic associations in 89 families with Birt-Hogg-Dube syndrome. Am J Respir Crit Care Med 2007;175:1044-53.

12. Xing H, Liu Y, Jiang G, et al. Clinical and genetic study of a large Chinese family presented with familial spontaneous pneumothorax. J Thorac Dis 2017;9:1967-72.

13. Hao S, Long F, Sun F, et al. Birt-Hogg-Dube syndrome: a literature review and case study of a Chinese woman presenting a novel FLCN mutation. BMC Pulm Med 2017;17:43.

14. Li T, Ning $X, \mathrm{He} Q$, et al. Novel germline mutations in FLCN gene identified in two Chinese patients with BirtHogg-Dube syndrome. Chin J Cancer 2017;36:4.

15. Dong L, Gao M, Hao WJ, et al. Case Report of BirtHogg-Dube Syndrome: Germline Mutations of FLCN Detected in Patients With Renal Cancer and Thyroid Cancer. Medicine (Baltimore) 2016;95:e3695.

16. So SY. Spontaneous pneumothorax due to Birt-HoggDube syndrome in a Chinese family. Respirology 2009;14:775-6.

17. Hou X, Zhou Y, Peng Y, et al. Birt-Hogg-Dube syndrome in two Chinese families with mutations in the FLCN gene. BMC Med Genet 2018;19:14.

18. Zhu JF, Shen XQ, Zhu F, et al. Novel folliculin (FLCN) mutation and familial spontaneous pneumothorax. QJM 2017;110:23-6.

19. Yang GG, Chiang CC. Recurrent spontaneous pneumothoraces. Am J Respir Crit Care Med 2013;188:e1-2.

20. Liu Z, Xu KF, Hu C, et al. Use of whole-exome sequencing for the diagnosis of atypical Birt-Hogg-Dube syndrome. J Genet Genomics 2014;41:449-51.

21. Lin Z, Gong K, Pang B, et al. Birt-Hogg-Dube syndrome with clear cell renal cell carcinoma in a Chinese family. Intern Med 2014;53:2825-8.

22. Ren HZ, Zhu CC, Yang C, et al. Mutation analysis of the FLCN gene in Chinese patients with sporadic and familial isolated primary spontaneous pneumothorax. Clin Genet 2008;74:178-83.

23. Kim KS, Choi HJ, Jang W, et al. Birt-Hogg-Dube Syndrome Manifesting as Spontaneous Pneumothorax: A Novel Mutation of the Folliculin Gene. Korean J Thorac Cardiovasc Surg 2017;50:386-90.

24. Kim J, Yoo JH, Kang DY, et al. Novel in-frame deletion mutation in FLCN gene in a Korean family with recurrent primary spontaneous pneumothorax. Gene 2012;499:339-42.

25. Shin WW, Baek YS, Oh TS, et al. Birt-hogg-dube syndrome, a rare case in Korea confirmed by genetic analysis. Ann Dermatol 2011;23:S193-6.

26. Park G, Kim HR, Na CH, et al. Genetic study in a case of birt-hogg-dube syndrome. Ann Dermatol 2011;23:S188-92. 
27. Kim EH, Jeong SY, Kim HJ, et al. A case of Birt-HoggDube syndrome. J Korean Med Sci 2008;23:332-5.

28. Inoue M, Miyazaki S, Kuno Y, et al. Birt-Hogg-Dube syndrome in the elderly. J Gen Fam Med 2018;20:72-3.

29. Yoshida K, Miyagawa M, Kido T, et al. Parotid Oncocytoma as a Manifestation of Birt-Hogg-Dube Syndrome. Case Rep Radiol 2018;2018:6265175.

30. Furuya M, Kobayashi H, Baba M, et al. Splice-site mutation causing partial retention of intron in the FLCN gene in Birt-Hogg-Dube syndrome: a case report. BMC Med Genomics 2018;11:42.

31. Iwabuchi C, Ebana H, Ishiko A, et al. Skin lesions of BirtHogg-Dube syndrome: Clinical and histopathological findings in 31 Japanese patients who presented with pneumothorax and/or multiple lung cysts. J Dermatol Sci 2018;89:77-84.

32. Takegahara K, Yoshino N, and Usuda J. A Case of Recurrent Pneumothorax Associated with Birt-HoggDube Syndrome Treated with Bilateral Simultaneous Surgery and Total Pleural Covering. Ann Thorac Cardiovasc Surg 2017;23:309-12.

33. Tanegashima T, Yamaguchi Y, Hamanoue H, et al. Clinical features of Birt-Hogg-Dube syndrome: A Japanese case with pulmonary cysts, fibrofolliculomas and renal cell carcinoma. J Dermatol 2017;44:1409-11.

34. Gunji-Niitsu Y, Kumasaka T, Kitamura S, et al. Benign clear cell "sugar" tumor of the lung in a patient with BirtHogg-Dube syndrome: a case report. BMC Med Genet 2016;17:85.

35. Matsutani N, Dejima H, Takahashi Y, et al. Birt-HoggDube syndrome accompanied by pulmonary arteriovenous malformation. J Thorac Dis 2016;8:E1187-9.

36. Miura K, Kondo R, Kurai M, et al. Birt-Hogg-Dube syndrome detected incidentally by asymptomatic bilateral pneumothorax in health screening: a case of a young Japanese woman. Surg Case Rep 2015;1:17.

37. Kamada T, Yoshikawa Y, Shirase T, et al. Perifollicular fibromas associated with Birt-Hogg-Dube syndrome. J Dermatol 2015;42:1194-5.

38. Nishida C, Yatera K, Yamasaki K, et al. Possible familial case of Birt-Hogg-Dube syndrome complicated with lung cancer: A possible link between these two disease entities. Respir Med 2015;109:923-5.

39. Yamada Y, Sakamoto S, Furuya M, et al. Case of bilateral and multifocal renal cell carcinoma associated with BirtHogg-Dube syndrome. Int J Urol 2015;22:230-1.

40. Murakami Y, Wataya-Kaneda M, Tanaka M, et al. Two Japanese cases of birt-hogg-dube syndrome with pulmonary cysts, fibrofolliculomas, and renal cell carcinomas. Case Rep Dermatol 2014;6:20-8.

41. Kunogi Okura M, Yae T, Nagashima O, et al. Pneumothorax developing for the first time in a 73-yearold woman diagnosed with Birt-Hogg-Dube syndrome. Intern Med 2013;52:2453-5.

42. Nishii T, Tanabe M, Tanaka R, et al. Unique mutation, accelerated mTOR signaling and angiogenesis in the pulmonary cysts of Birt-Hogg-Dube syndrome. Pathol Int 2013;63:45-55.

43. Kashiwada T, Shimizu H, Tamura K, et al. Birt-HoggDube syndrome and familial adenomatous polyposis: an association or a coincidence? Intern Med 2012;51:1789-92.

44. Tobino K and Seyama K. Birt-Hogg-Dube syndrome with renal angiomyolipoma. Intern Med 2012;51:1279-80.

45. Tobino K, Gunji Y, Kurihara M, et al. Characteristics of pulmonary cysts in Birt-Hogg-Dube syndrome: thinsection CT findings of the chest in 12 patients. Eur J Radiol 2011;77:403-9.

46. Misago N, Joh K, Yatsuki H, et al. A BHD germline mutation identified in an Asian family with Birt-HoggDube syndrome. Acta Derm Venereol 2008;88:423-5.

47. Motegi SI, Sekiguchi A, Fujiwara C, et al. A case of BirtHogg-Dube syndrome accompanied by colon polyposis and oral papillomatosis. Eur J Dermatol 2018;28:720-1.

48. Binet O RJ, Vicart M, Ventura G, et al. Fibromes perifolliculaires, polypose colique familiale,pneumothorax spontanés familiaux. Ann Dermatol Venereol 1986;113:928-30.

49. Roth JS, Rabinowitz AD, Benson M, et al. Bilateral renal cell carcinoma in the Birt-Hogg-Dube syndrome. J Am Acad Dermatol 1993;29:1055-6.

50. Gupta N, Seyama K, and Mccormack FX. Pulmonary manifestations of Birt-Hogg-Dube syndrome. Fam Cancer 2013;12:387-96.

51. Hartman TR, Nicolas E, Klein-Szanto A, et al. The role of the Birt-Hogg-Dube protein in mTOR activation and renal tumorigenesis. Oncogene 2009;28:1594-604.

52. Pavlovich CP, Grubb RL 3rd, Hurley K, et al. Evaluation and management of renal tumors in the Birt-Hogg-Dube syndrome. J Urol 2005;173:1482-6.

53. Schaffer JV, Gohara MA, Mcniff JM, et al. Multiple facial angiofibromas: a cutaneous manifestation of Birt-HoggDube syndrome. J Am Acad Dermatol 2005;53:S108-11.

54. Khoo SK, Giraud S, Kahnoski K, et al. Clinical and genetic studies of Birt-Hogg-Dube syndrome. J Med Genet 2002;39:906-12.

55. Pavlovich CP, Walther MM, Eyler RA, et al. Renal tumors 
in the Birt-Hogg-Dube syndrome. Am J Surg Pathol 2002;26:1542-52.

56. Zbar B, Alvord WG, Glenn G, et al. Risk of renal and colonic neoplasms and spontaneous pneumothorax in the Birt-Hogg-Dube syndrome. Cancer Epidemiol Biomarkers Prev 2002;11:393-400.

57. Byrne M, Mallipeddi R, Pichert G, et al. Birt-Hogg-Dube syndrome with a renal angiomyolipoma: further evidence of a relationship between Birt-Hogg-Dube syndrome

Cite this article as: Guo T, Shen Q, Ouyang R, Song M, Zong D, Shi Z, Long Y, Chen P, Peng H. The clinical characteristics of East Asian patients with Birt-Hogg-Dubé syndrome. Ann Transl Med 2020;8(21):1436. doi: 10.21037/atm20-1129 and tuberous sclerosis complex. Australas J Dermatol 2012;53:151-4.

58. Skolnik K, Tsai WH, Dornan K, et al. Birt-HoggDube syndrome: a large single family cohort. Respir Res 2016;17:22.

59. Zhu B, Wang Y, Ming J, et al. Disease burden of COPD in China: a systematic review. Int J Chron Obstruct Pulmon Dis 2018;13:1353-64. 